\title{
Transmission of Tobacco Necrosis Virus by Zoospores of Olpidium brassicae
}

\author{
By B. KASSANIS AND I. MACFARLANE \\ Rothamsted Experimental Station, Harpenden, Hertfordshire
}

(Received 16 January 1964)

\begin{abstract}
SUMMARY
Strain D of tobacco necrosis virus (TNV) was transmitted by zoospores of 3 different isolates of Olpidium brassicae (Wor.) Dang. to roots of Mung bean and lettuce grown in modified Hoagland's solution diluted 1/20. On Mung bean roots necrotic local lesions formed one day after exposure to virus and zoospores. Virus in lettuce was assayed by inoculation to leaves of French bean. Virus transmission was favoured by decreasing salt concentration and increasing the $\mathrm{pH}$ value of the nutrient solution and depended also on the concentrations of virus and zoospores. With $10^{5}$ zoospores $/ \mathrm{ml}$. transmission to lettuce was obtained with as little virus as $0.05 \mu \mathrm{g}$. $/ \mathrm{l}$. When the virus concentration was $5 \mu \mathrm{g}$./l., 50-100 zoospores/ ml. were effective. Fungus infection as measured by the number of zoosporangia in the root was not strictly correlated with virus infection.

Exposure of roots to virus + zoospore mixture for $1 \mathrm{~min}$. sufficed to infect them with virus. More transmission occurred when virus was added before or together with zoospores, than after. Roots, exposed to zoospores for $10 \mathrm{~min}$., then washed, were more readily infected by TNV when virus was introduced during the first hour or two after zoospore attachment to the root cells than later; there was some transmission even when virus was withheld till $4 \mathrm{hr}$ after washing. Immersing roots, inoculated with fungus and virus, in hot water $\left(60^{\circ}\right)$ killed the fungus but not the virus, and varying the interval between inoculation and heating showed that virus became established after $2-3 \mathrm{hr}$.

Isolates of Olpidium brassicae naturally contaminated by strain $\mathrm{D}$ or A of TNV were freed from contamination by inoculating lettuce roots with dilute zoospore suspensions. Zoospores mixed or naturally contaminated with TNV were partially separated from it by centrifugation. Virus transmission was prevented by adding concentrated homologous antiserum to zoospores that had already been exposed to virus, or by adding very dilute antiserum to virus before mixing it with zoospores. The extent to which transmission was prevented by antisera to other strains of TNV depended on the degree of their serological relationship to strain $\mathrm{D}$. The present evidence does not support the suggestion that TNV is carried inside the fungus.
\end{abstract}

\section{INTRODUCTION}

Tobacco necrosis virus (TNV) is soil-borne and often occurs in roots of normallooking plants but becomes systemic and causes an obvious disease in only a few species. Although first described some 30 years ago (Smith \& Bald, 1935), little was done until recently to find how it is transmitted. Bawden \& Kassanis (1947) suggested that soil micro-organisms might be vectors or reservoir hosts of TNV, but did not gain evidence for the idea from their tests with several soil bacteria and 
two soil fungi (Thielaviopsis basicola, Rhizoctonia solani) parasitic on tobacco. Other parasites in the roots of plants grown in infective soil were not tested and the eventual discovery that TNV is transmitted by the parasitic Chytrid fungus Olpidium brassicae (Wor.) Dang. was a by-product of research on 'big-vein' of lettuce (Teakle, 1960).

As an obligate intracellular parasite, Olpidium brassicae seems well fitted to transmit virus to plants it infects. The posteriorly uniflagellate zoospore attaches itself to a young root cell, encysts, and the contents of the cyst discharge into the host cell. The young thallus grows to form a zoosporangium, putting out discharge tubes to the exterior. Zoospores are differentiated and released, to repeat the infection process. Sometimes, zoospores function as gametes and the fusion body (perhaps the zygote) invades plant cells and becomes a thick-walled resistant sporangium. In favourable conditions the resistant sporangium releases zoospores to begin the life cycle anew (Meer, 1926; Jacobsen, 1943; Sahtiyanci, 1962).

Teakle $(1960,1962 a)$ found that roots of lettuce and Mung bean (Phaseolus aureus Roxb.) placed in a suspension of Olpidium brassicae zoospores containing TNV became infected with virus but did not do so in a solution of TNV alone. Since $O$. brassicae must be grown on its host plant and so far has not been obtained free from other micro-organisms, doubts must remain as to the identity of the transmitting agent. Teakle (1962 $a$ ) recognized this uncertainty and sought to show indirectly that $O$. brassicae transmitted the virus. He gave the following reasons in support of this conclusion: (1) Virus enters the root at about the same time as the fungus, i.e. 2-3 hr after inoculation. (2) Virus and zoospores enter on the same part of the root. (3) Treatments which decrease or stop the motility of the zoospores also decrease or prevent virus transmission. (4) The number of infections produced by washings from infected lettuce roots depends on their zoospore content. (5) Transmission is achieved by keeping roots in contact with virus and zoospores for only 1 min., after which the encysted zoospores are not removed by vigorous washing. (6) If an agent other than $O$. brassicae is involved, it is always present with $O$. brassicae. This evidence makes it highly probable that $O$. brassicae transmits the virus, and, at present, we accept this conclusion, which our results confirm. We now describe some factors which affect transmission of TNV by $O$. brassicae and results which bear on the mechanism of transmission.

\section{METHODS}

Plants. The variety Cheshunt 5B of lettuce (Lactuca sativa L.) was used to maintain Olpidium cultures and for the transmission experiments. Seeds were usually surface sterilized with Ca hypochlorite and germinated on filter paper, wet with tap water, at $18-20^{\circ}$. Two days later seedlings were transferred to water-culture vessels. Mung beans (Phaseolus aureus Roxb.) free from obvious damage or disease were treated with hypochlorite and germinated aseptically in Petri dishes on wet filter paper, at $20^{\circ} ; 2$ days later they were transferred to the culture vessels.

Sand culture and nutrient solution. Sand, in layers $2-3 \mathrm{~cm}$. deep, was autoclaved at $120^{\circ}$ for $1 \mathrm{hr}$. For cultivating Olpidium, plants were grown in small white polyethylene flower pots (rim diameter $5.5 \mathrm{~cm}$.) with the drainage hole plugged with glass wool. After use the pots were sterilized in a solution of sodium hypochlorite 
( $3 \mathrm{~g} . \mathrm{Cl} / \mathrm{l}$.) for $1 \mathrm{day}$, washed with detergent and again treated with hypochlorite. Plants in sand were grown in the glasshouse $\left(10-25^{\circ}\right)$ and in winter were given supplementary artificial light. Hoagland's solution (Hoagland \& Snyder, 1933), modified by doubling the standard concentration of $\mathrm{KH}_{2} \mathrm{PO}_{4}$, was used as a plant nutrient and as an infection medium. Iron was given as tartrate (Arnon, 1938) and micronutrients were as recommended by Arnon (1940).

Virus. Purified preparations of strain D of tobacco necrosis virus (TNVD) were used. The isolation and purification were described by Babos \& Kassanis (1963a).

Olpidium cultures. Three isolates of Olpidium brassicae (Wor.) Dang. were used. Olpidium 1 was isolated from lettuce grown in soil supplied by Dr J. A. Tomlinson from a big-vein site in Cheshire. TNVD and lettuce big-vein virus (Campbell \& Grogan, 1963) were associated with this isolate. Olpidium 2 was recultured from dried infected roots sent by Dr D. S. Teakle from California. Olpidium 3 was obtained from lettuce grown in unsterilized sand in unsterilized pots at Rothamsted; it was contaminated with TNVA and TNVD. The contaminated cultures were freed from TNV (see Results) and virus-free Olpidium was used in all transmission experiments unless otherwise mentioned. In referring our Olpidium cultures to the species $O$. brassicae (Wor.) Dang. we follow Sampson (1939); the question of nomenclature has been re-opened by Sahtiyanci (1962) and it might be argued that our cultures should be called Olpidium spp. (see Emerson, 1958). For convenience we shall call the fungus we have used simply Olpidium.

To obtain a regular supply of zoospore suspensions lettuces were grown in sand cultures automatically sub-irrigated with nutrient solution every $3 \mathrm{hr}$. Lettuce seedlings were grown in sand for about 2 weeks and then inoculated with the appropriate zoospore suspension. The intermittent flooding gave opportunities for zoospores to be released and re-infect the roots. Good yields of zoospores were obtained 1-2 weeks after inoculation. To obtain a zoospore suspension, a plant was removed from the irrigation tank and the sand allowed to dry slightly overnight. Next day the roots were quickly washed free from sand and put in a dish of culture solution diluted $1 / 20$. Zoospore release began within a few minutes and was usually allowed to continue for 10-15 min., when the suspension was filtered through stainless steel gauze to remove root fragments. Such a plant typically produced from 5 to $25 \times 10^{6}$ spores; some produced more.

Experimental procedure. Most transmission experiments were done with seedlings growing in culture solution and kept under fluorescent lights (18-hr day) in a basement room at $20^{\circ}$. Newly emerged seedlings of lettuce or Mung bean were transferred to vials 2 in. $\times 1$ in. containing $5 \mathrm{ml}$. nutrient solution, diluted $1 / 2$. The plants were supported on stainless steel mesh bent in the form of a table and with apertures that could be penetrated by the radicle but not by the hypocotyl of the seedling. The height of the support was such that $5 \mathrm{ml}$. fluid covered the young root and the vials were covered with a polythene sheet. Lettuce plants were inoculated 4 days later and Mung beans 1 day later. At inoculation the half-strength solution was decanted, replaced by solution diluted $1 / 20$ to which were usually added $1 \mathrm{ml}$. zoospore suspension in $1 / 20$ solution and $0.5 \mathrm{ml}$. containing virus. Unless stated otherwise, the final concentration of TNVD in the vials was $1.5 \mu \mathrm{g}$./l. Lettuce roots were assayed for virus by infectivity test 3 days later. Each lettuce root was washed under the tap, crushed with a pestle in a small glass mortar, and 
inoculated to the 4 primary leaves of 2 French bean plants (Phaseolus vulgaris, L., variety 'Prince') which had been dusted with Carborundum 600 mesh. The number of local lesions produced on the bean leaves 2-4 days later was a measure of the virus content of the root. Sap from washed roots primarily kept in solution containing virus alone at concentrations greater than $0.1 \mathrm{mg} / \mathrm{l}$. had some infectivity presumably because virus adhered to the surface of the root. This residual infectivity was diminished by dipping the roots in 'Teepol' before washing them. However, even without this treatment virus alone always gave root extracts much less infective than when virus was mixed with zoospores.

Infection of lettuce roots was detected by assays 2 days after inoculation; the infectivity of root extracts reached a maximum in 6-8 days. Extracts of infected roots of the variety 'Cheshunt $5 \mathrm{~B}$ ' were more infective than those from 'Great Lakes'. 'Cheshunt 5B' may be more susceptible to infection than the other, or produces more virus per infection centre, or both.

Twenty-four hours after inoculation with virus and zoospores, Mung bean roots develop small necrotic local lesions (Teakle, 1962b), countable with the aid of a hand lens, and probably reflecting single infection centres. Mung beans probably reflect the number of root infections better than lettuce. The number of lesions obtained in assays of lettuce roots will reflect the amount of virus produced in each infection centre as well as the number of infection centres. A possible advantage of using lettuce is that it may allow a few infections to be detected. Our results are expressed as mean numbers of lesions per Mung bean root or per bean leaf inoculated with a lettuce root extract. The means are based on all plants used in the transmission experiments, usually 4 lettuce or 8 Mung bean roots per treatment.

\section{Table 1. Virus transmission by Olpidium to lettuce roots at different virus concentrations}

Lettuce roots inoculated with virus alone at $6 \mu \mathrm{g}$./1. produced 0.2 lesions/bean leaf/root. Figures for virus and zoospores are the final concentrations in the vial.

\begin{tabular}{|c|c|}
\hline \multicolumn{2}{|c|}{ Virus inoculum } \\
\hline $\begin{array}{c}\text { Concentration } \\
(\mu \mathrm{g} . / 1 .)\end{array}$ & $\begin{array}{l}\text { Infectivity. Mean no. } \\
\text { lesions/leaf }\end{array}$ \\
\hline 6 & $\mathbf{5 3}$ \\
\hline $1 \cdot 2$ & 13 \\
\hline $0 \cdot 24$ & 1 \\
\hline 0.05 & $0 \cdot 2$ \\
\hline 0.01 & - \\
\hline
\end{tabular}

Infectivity of root extract. Mean number lesions/bean leaf/root

$\begin{array}{cc}\text { Olpidium 1 }_{\left(5 \times 10^{4} \text { zoosp. } / \mathrm{ml} .\right)} & \begin{array}{c}\text { Olpidium 2 } \\ \left(2 \times 10^{4} \text { zoosp. } / \mathrm{ml} .\right)\end{array} \\ 325 & 222 \\ 143 & 186 \\ 84 & 125 \\ 11 & 10 \\ 1 & 0\end{array}$

\section{RESULTS}

\section{Concentration of virus and zoospores}

With inocula containing many zoospores of any of the 3 Olpidia, lettuce roots became infected with TNVD when the virus in the inoculum was as dilute as 0.05 $\mu \mathrm{g} . / 1$. (Table 1). This is about the least virus concentration detectable by mechanical inoculation with carborundum to very susceptible French bean leaves.

Roots of young lettuce seedlings were infected by rubbing with a small stiff camel-hair brush dipped in virus and carborundum. This method succeeded only when the inoculum was $6 \times 10^{5}$ times more concentrated than needed for infection 
by Olpidium. Lettuce leaves were more easily infected than roots by brush inoculation; the minimal concentration of virus needed was $50 \mu \mathrm{g} . / 1$.

Some infected lettuce roots showed discoloured areas but infectivity tests showed that these were not connected with virus infection. The two lowest lettuce leaves sometimes developed minute necrotic local lesions when inoculated mechanically with TNVD, but at other times leaves became infected without showing lesions.

Experiments to find the fewest zoospores needed to transmit TNVD gave variable results (Table 2). However, with inoculum containing $5 \mu \mathrm{g}$. virus/1., 50-100 zoospores $/ \mathrm{ml}$. usually gave some virus infections. The number of virus infections produced depends on the concentration of virus (compare experiments 1 and 2, Table 2) and of zoospores, and over a limited range of concentrations decreasing one was compensated by increasing the other.

\section{Table 2. Virus transmission at different zoospore concentrations}

Olpidium 2 was used for all the experiments except for experiment 8 when Olpidium 8 was taken from lettuce also infected by virus. Virus concentration in vial was: $7,0 \cdot 35$, 1.6, 4.6 and $46 \mu \mathrm{g}$./1. for experiments $1,2,4,5,6$, respectively.

\begin{tabular}{|c|c|c|c|c|c|c|}
\hline & & $\operatorname{axp} n$ & & & xp. $n$ & \\
\hline Zoospores/ & $\begin{array}{r}1 \\
\text { In } \\
\text { Mean }\end{array}$ & $\begin{array}{r}2 \\
\text { Lettuc } \\
\text { of ro } \\
\text { f lesic }\end{array}$ & eaf/root & $\begin{array}{r}4 \\
\text { Total }\end{array}$ & $\begin{array}{c}5 \\
\text { ing } b \\
\text { of le }\end{array}$ & $\begin{array}{c}6 \\
\text { root }\end{array}$ \\
\hline $9 \times 10^{8}$ & 318 & 211 & 一 & - & - & - \\
\hline $3 \times 10^{3}$ & - & - & - & 184 & 131 & 856 \\
\hline $9 \times 10^{2}$ & 132 & 0 & - & - & - & - \\
\hline $6 \times 10^{2}$ & - & - & - & - & 12 & 109 \\
\hline $3 \times 10^{2}$ & - & - & 79 & 38 & 一 & 一 \\
\hline $9 \times 10$ & 118 & - & - & - & $\mathbf{1}$ & 18 \\
\hline $5 \times 10$ & - & 一 & 一 & 18 & - & 一 \\
\hline $3 \times 10$ & - & 一 & $\mathbf{0}$ & - & $\mathbf{0}$ & $\mathbf{0}$ \\
\hline $1 \times 10$ & o & - & - & 6 & - & - \\
\hline
\end{tabular}

Not all inoculated roots that became infected by Olipidium also contracted TNV infection. To find what correlation there was between fungus and virus infection, 4 roots inoculated 2 days previously were examined microscopically and the position of sporangia along the main root recorded. The roots were then cut into 7 sections of $5 \mathrm{~mm}$., each of which was macerated and inoculated separately to bean leaves. The number of sporangia in a root segment and the number of virus lesions produced in beans was not related. In many different experiments where virus and fungus infection was estimated in the same root no consistent relation was found between the two. It seems that conditions in the cell favourable for one might not always favour the development of the other. A possible conclusion is that virus infection may sometimes result from penetration by zoospores which do not develop further.

\section{Concentration and $p H$ value of the culture solution}

At the beginning of this work, zoospores were extracted in, and lettuce seedlings grown and inoculated in, the modified Hoagland's solution at half strength. However, it became apparent that this solution was not suitable for virus transmission by Olpidium. In several experiments when inoculated lettuce roots were washed 
in tap water at different times after inoculation, virus was not transmitted even when the interval between inoculation and washing was $3 \mathrm{hr}$, in contrast with Teakle's experience (Teakle, 1962a). Our failure was because of the concentration of the culture solution used; virus transmission by Olpidium improved when the solution was diluted. In one comparison, extracts from plants grown in solution diluted $1 / 2$ gave an average of 69 lesions per bean leaf whereas in solution diluted $1 / 20$ the average was 340 .

The effect of increasing salt concentration in decreasing virus transmission was greater when the inoculated roots were also subjected to other conditions unfavourable for transmission, such as acidity (Table 3). Virus transmissions by Olpidium were also tested at values above $\mathrm{pH} 7$. There was considerable transmission at $\mathrm{pH} 8$,

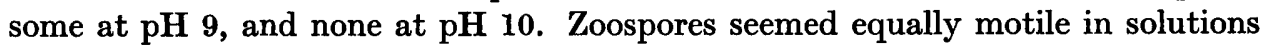
from $\mathrm{pH} 7$ to 9 ; they stopped swimming $3 \mathrm{hr}$ after extraction. At pH 9.5 they stopped swimming in about $1 \mathrm{hr}$ and at $\mathrm{pH} 10$ disintegrated in $5 \mathrm{~min}$.

Table 3. Virus transmission to lettuce roots by Olpidium in nutrient solutions of two salt concentrations and three $\mathrm{pH}$ values

Lettuce roots infected with Olpidium were divided into six portions and placed in the six solutions. The solutions in which the young lettuce seedlings were growing were replaced with the spore suspensions with added virus.

Zoospore concentrations varied from $4.5 \times 10^{4} / \mathrm{ml}$. to $1.8 \times 10^{5} / \mathrm{ml}$. but this variation did not affect virus transmission. The solution as prepared was at $\mathrm{pH} 4.5$; dilute $\mathrm{KOH}$ was used to adjust to other values.

\begin{tabular}{ccc} 
pH values & \multicolumn{2}{c}{$\begin{array}{c}\text { Infectivity of root extract. } \\
\text { Meanber of lesions/bean leaf/root }\end{array}$} \\
\cline { 2 - 3 } 4.5 & 6 & Solution $1 / 2$ \\
6 & 5 & 77 \\
7 & 145 & 358 \\
& & 927
\end{tabular}

Sequence of fungus and virus inoculations

Some experiments were made to find the time roots must be in contact with inoculum for the virus to infect. Lettuce roots were placed in a suspension containing $4 \times 10^{4}$ zoospores $/ \mathrm{ml}$. and $10 \mu \mathrm{g}$. virus/l., and after $1,5,30$, and $180 \mathrm{~min}$. were washed in running tap water and placed in fresh nutrient solution. Three days later the roots were tested for virus content and produced on average 64, 69, 60 and 65 lesions/bean leaf, respectively. Tests were made with Mung beans to determine the effectiveness in transmitting virus of (1) virus + zoospore mixture, (2) virus added before or (3) after a brief exposure to zoospores. The experimental treatments were: (1) Roots exposed to virus + zoospore mixture for 5 min., washed and placed in fresh nutrient solution. (2) Roots exposed to virus for $30 \mathrm{~min}$., washed and placed in fresh solution containing zoospores. Five minutes later the roots were washed again and placed in fresh solution. (3) Roots exposed to zoospores for $5 \mathrm{~min}$., washed in running tap water and placed in fresh nutrient solution containing virus. The inocula contained $6 \times 10^{4}$ zoospores $/ \mathrm{ml}$. and $0 \cdot 14 \mathrm{mg}$. virus $/$ l. The average number of lesions, when the root extracts were inoculated to bean leaves were 80 , 90 and 36, respectively, showing more infection when virus was added to the roots before or together with zoospores than when virus was added after zoospores, even 
though in the last treatment virus was present in the solution until next day when the lesions were counted. To obtain further information about this, an attempt was made to find how long the introduction of virus can be delayed after the roots are

\section{Table 4. Virus transmission to Mung bean roots by varying the interval between inoculation with Olpidium and virus}

Olpidium zoospores were added to Mung bean seedlings in vials at concentrations of $3 \times 10^{4}$ to $6 \times 10^{4} / \mathrm{ml}$. After $10 \mathrm{~min}$. the roots and vials were washed in tap water and solution replaced in vials. Virus was added at intervals, giving a final concentration of $1.6 \mu \mathrm{g} . / 1$. In experiments 1 and 2 the roots were left with virus until lesions developed. In experiment 3 roots were washed after $10 \mathrm{~min}$. exposure to virus and solution replaced in vials.

\begin{tabular}{|c|c|c|c|}
\hline \multirow[b]{2}{*}{$\begin{array}{l}\text { Time interval } \\
\text { between fungus } \\
\text { and virus } \\
\text { inoculation }\end{array}$} & \multicolumn{3}{|c|}{ Exp. no. } \\
\hline & $\begin{array}{c}1 \\
\text { (6 roots) } \\
\text { Tota }\end{array}$ & $\begin{array}{c}2 \\
\text { (7 roots) }\end{array}$ & $\begin{array}{l}\quad 3 \\
\text { (8 roots) } \\
\text { roots }\end{array}$ \\
\hline None & 68 & 166 & 77 \\
\hline $10 \mathrm{~min}$. & 34 & - & - \\
\hline $20 \mathrm{~min}$. & 46 & - & - \\
\hline $30 \mathrm{~min}$. & - & 87 & 75 \\
\hline $\mathbf{1 ~ h r}$ & 35 & 43 & 54 \\
\hline $2 \mathrm{hr}$ & - & 20 & 5 \\
\hline $3 \mathbf{h r}$ & - & 11 & 6 \\
\hline $4 \mathrm{hr}$ & 一 & 5 & 5 \\
\hline $5 \mathrm{hr}$ & - & 0 & 1 \\
\hline
\end{tabular}

Table 5. Virus transmission to lettuce roots by zoospores heated at $50^{\circ}$ for different times or when inoculated roots were heated for 10 sec at $50^{\circ}$ at different times after inoculation

Final virus concentration $1.5 \mu \mathrm{g}$. $/ \mathrm{l}$., and zoospores $1.8 \times 10^{5} / \mathrm{ml}$. The zoospores were heated in $1 \mathrm{ml}$. of suspension in long narrow tubes of $4 \mathrm{~mm}$. inner diameter, sealed at one end. The tubes were dipped in large volumes of water at $50^{\circ}$. Roots to be heated were inoculated by placing them in virus + zoospore mixture for $30 \mathrm{~min}$. before being washed. The roots were dipped in hot water up to the hypocotyls. The times below refer to placing the roots in the inoculum.

Treatment

Zoospores heated for

10 sec.

30 sec.

60 sec.

Unheated spores

Virus alone

Roots heated

30 min. after inoculation

$1 \mathrm{hr}$ after inoculation

$2 \mathrm{hr}$ after inoculation

$3 \mathrm{hr}$ after inoculation
Infectivity of root extract.

Mean number lesions/bean leaf/root

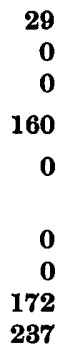

inoculated with zoospores, and still cause virus infection. Table 4 shows that a delay of 1-2 hr greatly decreased virus transmission but there was some transmission even when virus was withheld for $4 \mathrm{hr}$.

Teakle (1962a), by heating inoculated Mung bean roots for 10 sec. at $50^{\circ}$ (which 
kills zoospores but not virus), found that the shortest time necessary for the virus to become established in the host cell was between 2 and $3 \mathrm{hr}$. We confirmed this result with lettuce seedlings, but found that the virus was established within 1-2 hr after inoculation. This is within the period of 2-4 hr observed by Meer (1926) and Jacobsen (1943) to be necessary for zoospore penetration. The results in Table 5 show the effect of heating zoospores in suspension and when attached to roots. Under our conditions zoospores become motionless after being heated for $10 \mathrm{sec}$. at $50^{\circ}$ but were able to transmit some virus.

When the suspension was heated for 30 sec., all ability to transmit virus was lost. However, fungus already attached to or even in the roots was destroyed after 10 sec. at $50^{\circ}$ as was shown by heating roots one day after inoculation. This was established by microscopic examination 2 days later to find whether zoosporangia had formed.

Because virus was transmitted when roots were washed after being dipped in virus solution and before inoculation with zoospores, we concluded that some virus became attached to the roots. This was also shown by direct inoculation to bean leaves of extracts of roots that had been left for $2 \mathrm{hr}$ in a solution containing $1 \mathrm{mg}$. virus/l. and washed. The average number of lesions/leaf was 5 in one experiment and 10 in another. Usually, in transmission experiments with zoospores, the inoculum contained between 10 and $1 \mu \mathrm{g}$. virus/l.; hence the residual infectivity of roots exposed to virus alone was very small.

\section{Washing zoospores by centrifugation after exposure to virus}

To find whether virus combines closely or loosely with zoospores, virus and zoospores were mixed and then centrifuged. The experimental conditions were such that centrifugation damaged the zoospores so much that several centrifugations were not possible. Nevertheless, even the few centrifugations possible provided some information. Zoospore suspensions in $5 \mathrm{ml}$. tubes were centrifuged for $5 \mathrm{~min}$. at $7000 \mathrm{~g}$ (Baird \& Tatlock, small angle centrifuge). Suspensions, tubes and buckets were chilled in ice-water beforehand. Only the top half of the supernatant fluid was used, and was carefully pipetted off. The tubes were drained, wiped with absorbent paper and the pellets resuspended in solution to the original volume. In one experiment, as well as centrifuging virus + zoospores, zoospores alone (Olpidium 1, $2 \times 10^{5}$ zoospores $/ \mathrm{ml}$.) were centrifuged first and their capacity to transmit virus then tested. The first part of Table 6 shows that the centrifugation removed all the zoospores from the suspension and that they could still transmit virus.

Another sample of the same zoospore suspension was mixed with virus, centrifuged, and the supernatant fluids and resuspended pellets, alone or after mixing with uncentrifuged zoospores or more virus, used to infect lettuce roots. The results obtained with supernatant fluid to which uncentrifuged zoospores were added did not show that virus had been removed by the zoospores during centrifugation. The resuspended pellet alone transmitted poorly but was more infective when mixed with virus to the original concentration (Table 6). Dilution, to the extent of resuspending what virus was left in the pellet and in the drained tube in the original volume of solution, clearly brought the concentration below that at which the virus was readily transmitted by the centrifuged zoospores. The residual virus in the pellet was more clearly shown in another experiment by centrifuging the resuspended 
first pellet and testing the consequent supernatant fluid and pellet (Table 7). The resuspended first pellet, when tested alone, did not transmit virus but did so when more virus was added. The second centrifugation gave a supernatant fluid from which uncentrifuged zoospores transmitted virus (showing that the virus present in the first pellet was not transmitted by the once-centrifuged zoospores). The resuspended pellet from the second centrifugation still contained viable zoospores

Table 6. Virus transmission by zoospore suspensions centrifuged before or after mixing with virus

Final virus concentration in vials $20 \mu \mathrm{g} . / 1$, and of zoospores $3 \times 10^{4} / \mathrm{ml}$. when added after centrifugation. The volume in all treatments was equalized with nutrient solution.

\section{Treatment}

Centrifuged before mixing

Supernatant fluid with virus added

Resuspended pellet with virus added

Centrifuged after mixing

Supernatant fluid

Supernatant with uncentrifuged fungus added

Resuspended pellet

Resuspended pellet with virus added

Virus alone
Infectivity of root extract. Mean number lesions/ bean leaf/root

$$
1
$$

308

16

170

Table 7. Virus transmission by zoospore suspensions containing virus after one or two successive centrifugations

Final virus concentration in vials $10 \mu \mathrm{g} . / 1$. when added after centrifugation, initial zoospore concentration of Olpidium 1 was $1.4 \times 10^{6} / \mathrm{ml}$, final concentration when added after centrifugation was $2 \times 10^{5} / \mathrm{ml}$.

Treatments

Infectivity of root extract. Mean number of lesions/bean leaf/root

1st centrifugation

Supernatant

Supernatant with uncentrifuged

zoospores

Resuspended pellet

Resuspended pellet with new virus

2nd centrifugation

Supernatant

Supernatant with uncentrifuged

zoospores

Resuspended pellet

Resuspended pellet with new virus

Controls

Virus alone

Uncentrifuged zoospores and virus

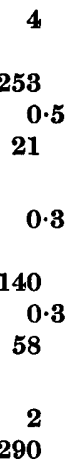

able to infect roots when mixed with fresh virus. The supernatant fluid from the first and second centrifugations inoculated to bean leaves gave averages of 29 and 0.7 lesions/leaf, respectively. Microscopical observation showed that centrifugation 
had damaged many of the zoospores and in this experiment the centrifuged zoospores were clearly unable to transmit the small amount of virus remaining, although uncentrifuged zoospores could. The importance of the interaction between zoospore concentration and virus concentration in virus-transmission experiments has already been noted. Caution is therefore necessary in interpreting the results of the centrifugation experiments lest freedom from virus be overestimated. That said, this experiment, like the previous one, suggests that the centrifuged zoospores, some of which at least were still able to transmit the virus, had not appreciably combined with virus before centrifugation.

Similar results were obtained by centrifuging a zoospore suspension $\left(2.5 \times 10^{5}\right.$ zoospores $/ \mathrm{ml}$.) of Olpidium 3 from a virus infected plant. The first supernatant fluid did not transmit virus except when mixed with uncentrifuged zoospores of Olpidium 2. The resuspended pellet was infective but much more so when mixed with more virus. When the suspended pellet $\left(1.7 \times 10^{5}\right.$ zoospores $/ \mathrm{ml}$.) was centrifuged again, there was still considerable virus in the supernatant fluid; this when mixed with uncentrifuged zoospores of Olpidium 2 infected all 4 lettuce roots. Extracts from these roots produced on average 234 lesions/bean leaf. The resuspended pellet of the second centrifugation when used alone did not transmit virus but did so after being mixed with more virus. These results suggested that centrifugation might be used to free Olpidium from TNV, but our attempt to do so failed.

The extent to which centrifugation damaged zoospores differed at different times and sometimes only occasional zoospores retained their motility. Zoospores survived better when some serum was added to the suspension before centrifugation. How many of the zoospores remained viable is unknown.

\section{Freeing Olpidium cultures from contamination with virus}

Further evidence that TNV and Olpidium are only loosely associated was obtained when the isolates which were naturally contaminated with TNV were freed from virus. This was accomplished on three occasions by adding highly diluted (1/1000-1/10,000) spore suspensions to vials each containing two lettuce seedlings. Infectivity tests and microscopical examination of respective roots showed that plants in a few vials were infected with fungus alone whereas those in the other vials had both fungus and virus.

Infectivity tests showed that virus was present in suspensions of zoospores from plants infected with virus-contaminated Olpidium but there was no correlation between numbers of zoospores and amount of virus released as shown by extracts from roots in small lots of culture solution at $5 \mathrm{~min}$. intervals. This may also explain how an Olpidium culture, contaminated with TNV could be freed from virus. In contrast to TNV, lettuce big-vein virus was not separated from Olpidium in this way. Olpidium 1 has been maintained free from TNV for the past 2 years but, although recultured many times, still carries big-vein virus.

\section{Effect of antisera on virus and zoospore mixtures}

Teakle \& Gold (1963) reported that virus transmission was prevented by an antiserum to TNV diluted 1/50, when mixed with virus before zoospores were added, but not after. They concluded from this 'that the Olpidium zoospore acquires and 
harbours TNV in such a manner that antiserum cannot inactivate it. Therefore it is probably not merely a surface carriage.' Our antiserum to TNVD at a dilution of $1 / 20$ stopped virus transmission when added either before or after virus was mixed with zoospores. Table 8 shows that when homologous antiserum was added before virus met zoospores, virus transmission was prevented in all experiments, whereas when added $5 \mathrm{~min}$. after virus and zoospores were mixed transmission was prevented in 5 of 7 experiments and substantially diminished in the other two. Virus transmission was also considerably decreased when antiserum was added to the roots either after contact with virus for $5 \mathrm{~min}$. and before zoospores were added, or

Table 8. Virus transmission by Olpidium in the presence of homologous antiserum or serum added before or after the virus was mixed with zoospores

\begin{abstract}
$\mathrm{V}$, virus ; Z, zoospores; $A / S$, homologous antiserum; $S$, normal serum. In treatments 1-6 virus was mixed in test tubes with nutrient solution, $A / S, S$ or zoospores for 5 min., then appropriate additional components added. All suspensions were brought to the same volume before $2.5 \mathrm{ml}$. of the final mixture was distributed to each vial. The dilution of $A / S$ or $S$ when it met the virus was always $1 / 20$. Final concentration of virus in the vial was $5 \mu \mathrm{g}$. $/ 1$. and that of zoospores $2.6 \times 10^{4}$ to $8.6 \times 10^{4} / \mathrm{ml}$.
\end{abstract}

Lettuce with Olpidium 1. Olpidium 2.

Treatment Exp. no.

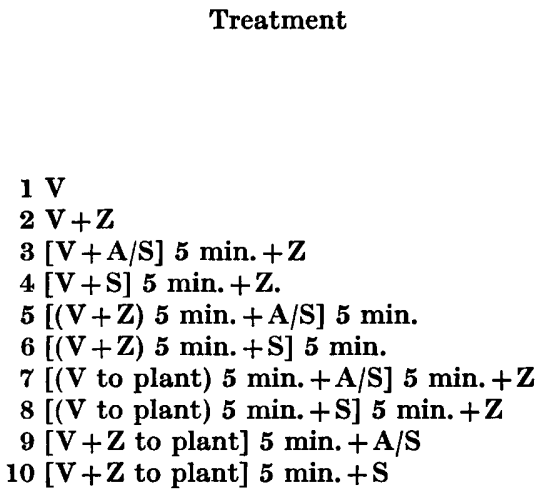

\begin{tabular}{|c|c|c|c|c|c|c|}
\hline 1 & 2 & $\mathbf{3}$ & 4 & 5 & 6 & $\gamma$ \\
\hline \multicolumn{6}{|c|}{$\begin{array}{l}\text { Infectivity of root extract. } \\
\text { Mean number of lesions/bean leaf/root }\end{array}$} & Number \\
\hline $\mathbf{0}$ & 0 & 0 & - & - & 0 & - \\
\hline 71 & 197 & - & - & 478 & 195 & 112 \\
\hline 0 & 0 & $\mathbf{0}$ & - & 2 & 0 & - \\
\hline- & 165 & 313 & - & - & - & - \\
\hline 0 & 4 & 0 & 28 & 149 & 2 & 0 \\
\hline- & - & 294 & 559 & - & - & 144 \\
\hline 0 & $\mathbf{5 0}$ & - & - & - & 一 & - \\
\hline- & 191 & - & - & - & - & - \\
\hline- & 10 & 15 & - & - & - & 112 \\
\hline- & 243 & 97 & - & - & - & 224 \\
\hline
\end{tabular}

5 min. after the roots came in contact with the virus + zoospore mixture. Much more dilute antiserum prevented transmission when mixed with virus and the zoospores added later, than when virus and zoospores were mixed first. The top part of Table 9 shows the effect of adding antiserum to virus before adding zoospores. Our antiserum to TNVD completely stopped virus transmission at a dilution of $1 / 2500$ and decreased transmission at $1 / 12,500$. Teakle \& Gold (1963), with the same mixing sequence, did not prevent transmission when they diluted their antiserum from $1 / 50$ to $1 / 100$ and doubled the virus concentration. This suggests that their antiserum contained less antibody. The results with the two heterologous antisera (Table 9) show that antiserum to TNVE, which is closely related serologically to TNVD, was nearly as effective as antiserum to TNVD in preventing virus transmission by Olpidium. By contrast, antiserum to TNVA, which is only remotely related serologically to TNVD, had little effect in preventing virus transmission. Teakle \& 
Gold's results resemble ours with antiserum to TNVA. There is no information that their virus culture contained only one strain of TNV and their antiserum may have been prepared against one strain of virus and used in transmission experiments against another. The second part of Table 9 shows that the three antisera similarly differed when virus and zoospores were mixed first, but that the antiserum then needed to be more concentrated to prevent transmission.

\section{Table 9. Virus transmission to lettuce or Mung bean roots by Olpidium in the presence of antisera added before or after virus was mixed with zoospores}

The treatments were similar to 3 and 5 in Table 8 . Virus was mixed in test tubes with A/S and nutrient solution or zoospores : after 5 min., as appropriate, A/S or zoospores were added so that virus always met $A / S$ at constant volume. The dilutions of $A / S$ given in the table are those at which the $A / S$ met the virus. When an $A / S$ was diluted more than $1 / 20$, the concentration was made up by addition of normal serum. Final concentrations in vial: of virus $1 \mu \mathrm{g} . / 1$. and of zoospores $1.2 \times 10^{5} / \mathrm{ml}$.

Treatment

Antiserum added to virus before zoospores

A/S to TNVD dil. $\begin{aligned} & 1 / 2500 \\ & 1 / 12,500 \\ & 1 / 62,500\end{aligned}$

A/S to TNVE dil. $1 / 2500$

$$
1 / 12,500
$$$$
1 / 62,500
$$

A/S to TNVA dil. $1 / 100$

$1 / 500$

$1 / 2500$

\author{
Lettuce with \\ Olpidium 1. \\ Infectivity of root \\ extract \\ Mean number of \\ lesions/bean leaf/root
}
Mung bean with Olpidium 2.
Number of lesions on 8 roots

Antiserum added to virus after zoospores

$\begin{array}{llrr}\text { A/S to TNVD dil. } & 1 / 20 & 3 & 8 \\ & 1 / 100 & 17 & 19 \\ \text { A/S to TNVE dil. } & 1 / 20 & 22 & 53 \\ & 1 / 100 & 41 & 142 \\ \text { A/S to TNVA dil. } & 1 / 20 & 203 & 103 \\ & 1 / 100 & 250 & 256\end{array}$

The precipitation titres of the three antisera when tested against TNVD at 40 mg./l., were $1 / 320,1 / 80$ and $1 / 5$ for antisera to TNVD, TNVE and TNVA, respectively. These values measure the serological relationships already mentioned and the effects on transmission rank in the same order. In addition, the relative effects of the three antisera in stopping transmission of virus by Olpidium, irrespective of the order of mixing, are nearly proportional to their precipitation titres. This suggests that precipitating antibodies may be responsible for the phenomenon.

Table 10 shows that prevention of virus transmission by homologous antiserum, when added $5 \mathrm{~min}$. after virus and zoospores were mixed, depended on the ratio of virus to antiserum and not on a particular antiserum dilution. In a factorial experiment with Mung bean roots a comparison was made of the effects of two concentrations each of antiserum, virus and zoospores and of adding the antiserum 
5 or $20 \mathrm{~min}$. after virus and zoospores were mixed. The results showed that the extent to which the antiserum inhibited virus transmission depended not only on virus concentration and number of zoospores but to some extent on the time virus and zoospores were left together before adding antiserum.

Table 10. Virus transmission to lettuce by Olpidium when homologous antiserum was added to virus + zoospore mixture at two concentrations of virus and antiserum

\begin{abstract}
Virus ( $0.5 \mathrm{ml}$.) and zoospores $(5 \mathrm{ml}$.) were mixed in test tubes and after $5 \mathrm{~min} .5 \mathrm{ml}$. of antiserum $1 / 10$ or $1 / 30$ were added. When antiserum $1 / 30$ was used, concentration was made up with normal serum. Two ml. of mixture was put in each vial. Final concentration in vial of zoospores was $1.4 \times 10^{5} / \mathrm{ml}$.
\end{abstract}

$\begin{array}{ccc}\begin{array}{c}\text { Final virus concentration } \\ (\mu \mathrm{g} . / \mathrm{l} .)\end{array} & \begin{array}{c}\text { Dilution of } \\ \text { antiserum } \\ \text { added }\end{array} & \begin{array}{c}\text { Infectivity of root extract } \\ \text { Mean number lesions/ } \\ \text { bean leaf/root }\end{array} \\ 1.4 & 1 / 10 & 15 \\ 1.4 & 1 / 30 & 54 \\ 0.07 & 1 / 10 & 0 \\ 0.07 & 1 / 30 & 0.5 \\ 0.07 \text { Normal serum } & 1 / 10 & 251 \\ 1.2 \text { Virus alone } & - & 0\end{array}$

Sometimes virus transmission was increased when normal serum was added to virus zoospore mixture; Olpidium infection of the inoculated roots was enhanced when normal serum or antiserum was added to the mixture. Consequently, roots inoculated with a virus + zoospore mixture, to which antiserum was added after mixing virus with zoospores, had numerous zoosporangia but little or no virus. The results with antiserum are compatible with the idea that during infection the virus is outside the zoospores, because even when antiserum was added 20 min. after virus and zoospores were mixed, virus transmission was prevented or greatly diminished. Much more antiserum was needed to stop virus transmission when the antiserum was added to the virus after zoospores than before. A possible explanation for this is that less antibody was sufficient to aggregate virus particles in solution but much more was needed to coat and make ineffective virus particles attached to the zoospore surface. The centrifugation experiments suggest that virus did not become closely bound to zoospore.

\title{
DISCUSSION
}

In general our results agree closely with those of Teakle but with some differences in the experiments with antisera. Our results support his conclusion (Teakle, $1962 a$ ) that Olpidium, and not some other agent present in the zoospore suspensions, was responsible for virus transmission. An agent of virus transmission other than Olpidium cannot be entirely excluded until Olpidium is cultivated free from other micro-organisms. Such doubt might arise from our observation that the number of zoosporangia in roots was not always correlated with the extent of virus infection, and sporangia and virus were not always found in the same root area. An occasional zoosporangium might be over-looked, but this cannot apply when many fungus sporangia were observed but no virus found. The entry of virus simply when Olpidium zoospores are present elsewhere in the same medium must be discounted because, 
in experiments not reported here, cell-free filtrates from zoospore suspensions, in which numerous seedling roots were suspended for $1 \mathrm{hr}$, did not transmit virus. Unless the conclusion that TNV is transmitted by Olpidium is wrong, the most likely explanation for the results is that penetration by the zoospores is sufficient to allow the virus to enter, but the fungus need not develop and produce zoosporangia. The experiment in which inoculated roots were heated to kill the fungus, but in which virus nevertheless multiplied, shows that this is possible. Similarly, virus may have failed to multiply in some cells in which fungus developed.

If Olpidium be accepted as a vector of TNV then it is a very efficient one, especially when the difficulty of transmitting the virus by rubbing the roots of lettuce plants is considered. Natural transmission of TNV through the soil when roots are abraded by soil particles is therefore unlikely to occur, although experimental conditions have been described where this may have happened. Root infection in naturally infected soils can be stopped by adding the fungicide Captan at $2 \mathrm{~g} . / \mathrm{kg}$. of soil. However, if in an autoclaved soil virus is added then roots can be infected even when Captan is added, and Babos \& Kassanis (1963b) concluded that virus can be transmitted by abrasion provided there is enough virus in the soil.

Virus transmission by Olpidium depends on the concentration of virus and of zoospores. The effectiveness of zoospores tended to differ considerably from one experiment to another, but there was no evidence that fewer zoospores could cause virus transmission when taken from roots also infected with virus than when taken from virus-free roots and mixed with purified virus. Such a difference might be expected if the virus entered the fungus when the two were multiplying in the same cell, unless the free zoospores take up virus very rapidly.

The experiments with antisera suggested that the virus is on the zoospore surface and if this is so the centrifugation experiments showed that the attachment is loose. The zoospores while in contact with virus in suspension, before and during centrifugation, did not acquire enough virus to infect the roots. Similarly, zoospores from roots also infected with TNV, and perhaps present with the virus in the same cell, were separated from virus by centrifugation. The comparative ease with which virus-free Olpidium cultures were obtained from spore suspensions from virusinfected roots suggests that there is no intimate association between zoospores and virus.

The simplest explanation of transmission is that virus enters the host by the same route as does the fungus. Transmission appears to be most certain when virus is already attached to the area of the root cell wall through which the zoospore will penetrate. Virus particles would then almost inevitably be pushed into the host cell by the advancing front of the zoospore. However, some virus infection occurs when virus is added even $4 \mathrm{hr}$ after zoospores have become attached to the cell wall. If virus particles can penetrate the zoospore cyst they could follow or attach to the penetrating protoplast. The diminishing chances of virus transmission after zoospore attachment might relate to changes in the cyst wall or to an increasing proportion of the attached zoospores having completed penetration when, presumably, the breach in the cell wall is repaired. Alternatively, virus may enter the host cell in the vicinity of the path of the zoospore (where the cell wall must in some way be altered at least temporarily) and the ease with which virus can invade here may decrease with the progress of penetration by the zoospores. 
Teakle \& Gold (1963) failed to transmit some other viruses which, in size and shape, resemble TNV. This does not necessarily mean that there is some special relationship between TNV and Olpidium. Possibly other viruses morphologically similar to TNV also enter the cell at the entry point of the zoospore but the metabolism of the cell as it is changed by the fungus is suitable only for the multiplication of TNV. Equally, two strains of Olpidium may affect the cell differently and one leave conditions suitable for the multiplication of TNV but the other not. A very similar situation may exist with the transmission by aphids of the non-persistent viruses. It is generally accepted that these viruses are transmitted mechanically on the tips of the aphid stylets. Nevertheless, there is vector specificity. For example, one species of aphid can transmit one particular strain of cucumber mosaic virus but not another (Badami, 1958).

\section{REFERENCES}

Arnon, D. I. (1938). Microelements in culture-solution experiments with higher plants. Am. J. Bot. 25, 322.

ARnon, D. I. (1940). Vitamin B, in relation to the growth of green plants. Science, 92, 264.

Babos, P. \& Kassanis, B. (1963a). Serological relationships and some properties of tobacco necrosis virus strains. J. gen. Microbiol. 32, 135.

Babos, P. \& Kassanis, B. (1963b). The behaviour of some tobacco necrosis virus strains in plants. Virology, 20, 498.

BADAMI, R. S. (1958). Changes in the transmissibility by aphids of a strain of cucumber mosaic virus. Ann. appl. Biol. 46, 554 .

Bawden, F. C. \& Kassanis, B. (1947). Primula obconica, a carrier of tobacco necrosis viruses. Ann. appl. Biol. 34, 127.

Campbell, R. N. \& Grogan, R. G. (1963). Big-vein virus of lettuce and its transmission by Olpidium brassicae. Phytopathology, 53, 252.

Emerson, R. (1958). Mycological organization. Mycologia, 50, 589.

Hoagland, D. R. \& SNYDER, W. C. (1933). Nutrition of strawberry plant under controlled conditions: (a) Effects of deficiencies of boron and certain other elements: (b) Susceptibility to injury from sodium salts. Proc. am. Soc. hort. Sci. 30, 288.

Jaconsen, B. (1943). Studies on Olpidium brassicae (Wor.) Dang. Contr. Dep. Plant Path. R. Vet. \& Agric. Coll. Copenhagen, 24, 1.

Sahtiyanci, S. (1962). Studien über einige wurzelparasitäre Olpidiaceen. Arch. Mikrobiol. 41, 187.

SAmpson, K. (1939). Olpidium brassicae (Wor.) Dang. and its connection with Asterocystis radicis De Wildeman. Trans. Brit. mycol. Soc. 23, 199.

Sмiтh, K. M. \& BaLD, J. G. (1935). A description of a necrotic virus disease affecting tobacco and other plants. Parasitology, 27, 231.

TeakLe, D. S. (1960). Association of Olpidium brassicae and tobacco necrosis virus. Nature, Lond. 188, 431.

Teakle, D. S. (1962a). Transmission of tobacco necrosis virus by a fungus, Olpidium brassicae. Virology, 18, 224.

Teakle, D. S. (1962b). Necrotic symptoms of tobacco necrosis virus in roots. Phytopatho$\log y, 52,1037$.

Teakle, D. S. \& Goln, A. H. (1963). Further studies of Olpidium as a vector of tobacco necrosis virus. Virology, 19, 310.

vaN DER Meer, J. H. H. (1926). Rhizoctonia-en Olpidium-aantasting van Bloemkoolplanten. Tijdschr. PlZiekt. 32, 209. 